\title{
Volunteering and social engagement of medical students in South Korea during the COVID-19 pandemic
}

Yong-Hoon Lee, Jane $\mathrm{Ha}^{1}$ and Hyunmi Park ${ }^{2}$

${ }^{1}$ Korea University College of Medicine and ${ }^{2}$ Brain Convergence Research Center, Korea University College of Medicine, Seoul, Korea

\section{Problems we faced}

Due to the widespread outbreak of the coronavirus disease 2019 (COVID-19), many classroom-based lectures moved online, and medical school clinical clerkships were affected to differing degrees across the world [1]. While lectures and clerkships were on hold, medical students worldwide sought after their duties and social responsibilities in the midst of this pandemic. Here, we introduce medical student-led volunteering activities planned and performed in South Korea (Korea from here on) and share our thoughts on how to increase future participation by analyzing foreign medical students' volunteering activities in the literature.

\section{Student-led volunteerism}

Some volunteering activities from medical students abroad comprised of medical practices that met national medical demands for COVID-19 testing and patient care. We present some exemplary cases of students performing medical practices; In Switzerland, physicians in the Corona Task Force consisted of physicians who recruited and trained volunteer medical students in nasal and oropharyngeal swabs. Students participated in 936 shifts of COVID-19 testing under physician supervision due to the high demand for swab-testing workforce [2]. Medical students who ran the Cardinal Free Clinics, an already existing student-run free clinics from Stanford University, developed a telehealth clinic model to continue providing medical service while the physical clinics were forced to close due to the pandemic situation [3]. In addition to running the clinics using a video platform, they also assessed social needs to address patient hardships during the pandemic.

Other non-clinical activities led by medical students included support for health care workers. One of the committees organized by students at Harvard Medical School named "Community Activism" conducted and performed activities such as assisting childcare for
Received: August 2, 2021 • Revised: August 18, 2021 • Accepted: September 3, 2021 Corresponding Author: Hyunmi Park (https://orcid.org/0000-0002-4134-2213) Brain Convergence Research Center, Korea University College of Medicine, 73 Goryeodae-ro, Seongbuk-gu, Seoul 02841, Korea

Tel: +82.2.2286.1238 email: hyunmipark@korea.ac.kr
Korean J Med Educ 2021 Dec; 33(4): 441-444 https://doi.org/10.3946/kjme.2021.212 eISSN: 2005-7288

(C) The Korean Society of Medical Education. All rights reserved. This is an open-access article distributed under the terms of the Creative Commons Attribution Non-Commercial License (http:// creativecommons.org/licenses/by-nc/3.0/), which permits unrestricted non-commercial use, distribution, and reproduction in any medium, provided the original work is properly cited. 
Yong-Hoon Lee, et al: Social engagement of Korean medical students during pandemic

hospital staffs or delivering groceries for the elderly or immunocompromised individuals who had difficulties going outside during the pandemic [4]. Students from the University of Nebraska Medical Center collected and distributed personal protective equipment and coordinated community mask sewing to support frontline health care workers [5].

Despite the lack of formalized volunteering activities, Korean medical students found social needs that could be addressed as a group. Medical students, together with attending and resident doctors in Korea, participated in a blood donation relay which started on August 7th, 2020 [6]. During the first week, a total of 1,362 donors participated, and all donation certificates, worth one unit of packed red blood cell transfusion each, were donated to the Korea Childhood Leukemia Foundation and training hospitals. Thirteen medical schools continued with this relay. Medical students utilized social media to encourage further participations from colleagues by uploading, sharing, and tagging each other, resulting in the exponential increase in the number of participants. This activity intended to overcome a blood bank crisis during COVID-19 by sharing information and encouraging blood donation participation amongst their peers.

A volunteering activity that medical students participated during clinical practice took place in December 2020 [7]. Under the supervision of qualified physicians, the Volunteer Corps of Korean Medical Students organized by fourth year students performed nasal swab tests in temporary triage rooms for three weeks. Integrated to the Central Disaster and Safety Countermeasures Headquarters, a total of 300 medical students were gathered and performed diagnostic swabs.

The student council of Korea University College of Medicine (KUCM) organized a volunteer team and visited an underserved village with a cluster of extremely small houses on August 14th, 2020. Information was recorded by the authors through an interview on April 2021 with one of the students who planned and participated in the volunteering activity. To minimize the risk of COVID-19 infection, a limited group of nine first to fourth year medical students gathered in a team. The village was comprised of small housing space that could only accommodate two people lying down, the residents shared toilets, were exposed to poor hygiene environments, and were thought to be very vulnerable to infectious diseases. Considering that these villages were one of the blind-spots for the government's preventive measures, KUCM students planned and volunteered in disinfecting the residential place, educating the residents about preventive measures against epidemics, and provided necessities including water and hand sanitizers. A total of 250 residences were disinfected between the nine medical students with each spending an average of 5 minutes per house.

\section{Our thoughts}

The volunteering activities of Korean medical students did not follow the organized pattern or scale described in other countries. The authors believe that one of the reasons underlying the lack of voluntary medical practices performed by students was the absence of a structured volunteering curriculum in Korean medical colleges. In Korea, similar to other countries, clinical activities performed by medical students should be under strict supervision of licensed physicians. This legally binding rule adds to the substantial public's intolerance on any kind of clinical activities performed by medical students. During March 2020, Daegu was the hotspot for the first wave of COVID-19 infections in Korea. A recruiting announcement of medical students to help in 
volunteering activities was met with great public uproar. The public's anger against medical practices of any kind, regardless of supervision or public health crisis situation, by unlicensed medical students ultimately cancelled any kind of potential voluntary work [8].

The pandemic has given rise to student-led free clinics to be integrated into the medical school curriculum in countries such as Australia, Canada, United States, and Germany where students participated in the provision of health care for underserved populations [9,10]. Asklepios Medical School maintained this system by recruiting one licensed health care professional for supervising and educating three students per session as a team [9]. Students had to complete an extensive training program before joining such team. Unless these curricula are introduced into our regular medical school programs, student-based medical volunteering in a large group may be difficult to accomplish without rigorous training and supervision to appease the wary public.

Korea's early pandemic response led to a relatively brief 3-week average suspension of clinical rotations for the start of the academic year in March 2020, which was shorter than in other parts of the world [1]. The lack of organized institutional volunteering activities like those seen in other countries may have been due to the rapid resumption of the normal clinical curricula and the absence of national or regional lockdowns.

Korean students could still perform volunteering activity through the government-managed service operated by the Ministry of Health and Welfare matching the supply and demand of volunteers, but this was not clinically relevant as it was open to the general public. Korean students used the Volunteer Management System (www.vms.or.kr) to apply for various volunteering programs individually to contribute to society instead of organizing their own task force as medical students abroad.
Published studies state that medical students participating in student-run free clinics experienced an improvement in knowledge, skills, and attitudes through their volunteering activities [11]. Students also reported to have developed empathy, heightened social awareness, and increased their interest in helping underserved populations [12], which are virtues defined as the principle of primacy in patient welfare and the principle of social justice in terms of medical professionalism.

In addition to the medical knowledge that students have to learn during medical education, there are numerous and priceless virtues in medical professionalism that we must possess before practicing medicine as licensed clinicians. By participating in volunteering activities, students would be provided with opportunities to learn both knowledge and medical professionalism. For an enriched and high-quality education, we aspire for increased systematic volunteering activities at the individual, medical student association, and institutional levels as well as activities led by local and central governmental bodies.

\section{ORCID:}

Yong-Hoon Lee: https://orcid.org/0000-0001-8240-0515; Jane Ha: https://orcid.org/0000-0002-6175-8793; Hyunmi Park: https://orcid.org/0000-0002-4134-2213

Acknowledgements: The authors thank Professor Young-Mee Lee for her valuable guidance and support for this manuscript.

Funding: No financial support was received for this study.

Conflicts of interest: No potential conflict of interest relevant to this article was reported.

Author contributions: YHL: conceptualization, drafting the manuscript; JH: drafting the manuscript; HP: supervision, critical revision. 


\section{References}

1. Park H, Lee YM, Ho MJ, Han HC. How the coronavirus disease 2019 pandemic changed medical education and deans' perspectives in Korean medical schools. Korean J Med Educ. 2021;33(2):65-74.

2. Klasen JM, Meienberg A, Nickel C, Bingisser R. SWAB team instead of SWAT team: medical students as a frontline force during the COVID-19 pandemic. Med Educ. 2020;54(9):860.

3. Ruiz Colón G, Mulaney B, Reed RE, et al. The COVID-19 pandemic as an opportunity for operational innovation at 2 student-run free clinics. J Prim Care Community Health. 2021;12:2150132721993631.

4. Soled D, Goel S, Barry D, et al. Medical student mobilization during a crisis: lessons from a COVID-19 medical student response team. Acad Med. 2020;95(9): 1384-1387.

5. Kratochvil TJ, Khazanchi R, Sass RM, Caverzagie KJ. Aligning student-led initiatives and Incident Command System resources in a pandemic. Med Educ. 2020; 54(12):1183-1184.

6. Jang YS. Korean medical students are on blood donation wave. Health Focus. September 2, 2020. http://www. healthfocus.co.kr/news/articleView.html $? \mathrm{idxno}=97226$. Accessed July 20, 2021.
7. Kwon TH. Medical students join COVID-19 volunteering... into temporary screening clinic in capital area. SBS news. December 1 1, 2020. https://news.sbs.co.kr/news/endPage. do?news_id=N10061 18539\&plink=SEARCH\&cooper $=$ SBSNEWSSEARCH. Accessed July 20, 2021.

8. Huang BW. The argument of recruiting medical and nursing students for volunteering ends by canceling the whole project. Medical Times. March 9, 2020. http:// www.medicaltimes.com/Users/News/NewsView.html?ID =1132438. Accessed July 20, 2021.

9. Drexler R, Fröschle F, Predel C, et al. Establishing a student-run free clinic in a major city in Northern Europe: a l-year experience from Hamburg, Germany. J Public Health (Oxf). 2020;42(4):793-798.

10. Smith S, Thomas R 3rd, Cruz M, Griggs R, Moscato B, Ferrara A. Presence and characteristics of student-run free clinics in medical schools. JAMA. 2014;312(22): 2407-2410.

11. Lie DA, Forest CP, Walsh A, Banzali Y, Lohenry K. What and how do students learn in an interprofessional student-run clinic?: an educational framework for teambased care. Med Educ Online. 2016;21:31900.

12. Smith SD, Yoon R, Johnson ML, Natarajan L, Beck E. The effect of involvement in a student-run free clinic project on attitudes toward the underserved and interest in primary care. J Health Care Poor Underserved. 2014; 25(2):877-889. 